\title{
THE EFFECT OF LISTEN-READ-DISCUSS (LRD) STRATEGY ON READING COMPREHENSION OF THE SECOND YEAR STUDENTS AT SMK DAR EL HIKMAH PEKANBARU
}

\author{
Devi Lusiani ${ }^{1}$, Rumiri Aruan², Jismulatif $^{3}$ \\ 1,2,3 Universitas Riau, Pekanbaru, Indonesia \\ Idevilusiani30@gmail.com, ${ }^{2}$ rumiri.aruan@lecturer.unri.ac.id, ${ }^{3}$ jismulatif@lecturer.unri.ac.id
}

\begin{abstract}
This research was aimed to find out the significant effect of Listen-Read-Discuss (LRD) strategy on reading comprehension of the second year students at SMK Dar El Hikmah Pekanbaru. This research was Pre-experimental with one group Pre-test Post-test design. The population of this research was the second year students of SMK Dar El Hikmah Pekanbaru. All of the population were taken as the samples selected by using total sampling technique. This research administered a reading test consisting of 40 multiple-choice items in the pre-test and post-test. The mean score in pre-test was 60.15 while the mean score in post-test was 74.97. To determine the difference between pre-test and post-test, this research used t-test formula. After analyzing the data, it was found that the t-test score was 8.782 meaning that it was higher than t-table (2034). From the result of data analysis, it was concluded that the Alternative Hypothesis (Ha) of this research was accepted. Thus, Listen-Read-Discuss (LRD) strategy significantly improved the reading comprehension of the second year students at SMK Dar El Hikmah Pekanbaru. Based on these findings, it was recommended that Listen-Read-Discuss (LRD) strategy was effective on improving the students' reading comprehension, particularly in narrative text.
\end{abstract}

Keywords: effect, LRD strategy, reading comprehension

\section{PENGARUH PENGGUNAAN STRATEGI LISTEN-READ-DISCUSS (LRD) DALAM MENINGKATKAN PEMAHAMAN MEMBACA SISWA KELAS DUA SMK DAR EL HIKMAH PEKANBARU}

\begin{abstract}
ABSTRAK
Penelitian ini bertujuan untuk mengetahui pengaruh signifikan dari penggunaan strategi Listen-Read-Discuss (LRD) dalam meningkatkan pemahaman membaca siswa kelas dua SMK Dar El Hikmah Pekanbaru. Penelitian ini merupakan penelitian pra-eksperimental dengan desain satu kelompok pre-test post-test. Populasi dalam penelitian ini adalah siswa kelas dua SMK Dar El Hikmah Pekanbaru, kemudian menetapkan semua populasi sebagai sampel dengan menggunakan teknik total sampling. Penelitian ini menggunakan tes membaca yang terdiri dari 40 butir soal berupa pilihan ganda pada pre-test dan post-test. Nilai rata-rata dari pre-test adalah 60.15 , sementara nilai rata-rata dari post-test adalah 74.97 . Untuk mengetahui perbedaan antara pre-test dan post-test digunakan rumus $t$-test. Setelah dilakukan analisis data, diperoleh bahwa nilai $t$-test sebesar 8.782 yang berarti lebih tinggi dari nilai $t$-table (2034). Dari hasil analisis data tersebut dapat disimpulkan bahwa Hipotesis Alternatif (Ha) dari penelitian ini diterima. Ini berarti bahwa ada pengaruh yang signifikan dari penggunaan strategi Listen-Read-Discuss (LRD) dalam meningkatkan pemahaman membaca siswa kelas dua SMK Dar El Hikmah Pekanbaru.
\end{abstract}

Kata Kunci: efek, strategi LRD, pemahaman membaca

\begin{tabular}{|c|c|c|}
\hline Submitted & Accepted & Published \\
\hline 16 Februari 2021 & 22 April 2021 & 23 Mei 2021 \\
\hline
\end{tabular}

\begin{tabular}{|l|c|c|c|}
\hline Citation & $:$ & Lusiani, D., Aruan, R., \& Jismulatif, J. (2021). The Effect of Listen-Read-Discuss (LRD) Strategy on Reading \\
& $\begin{array}{l}\text { Comprehension of the Second Year Students at SMK Dar El Hikmah Pekanbaru. Jurnal PAJAR (Pendidikan dan } \\
\text { Pengajaran), 5(3), 684-691. DOI : http://dx.doi.org/10.33578/pjr.v5i3.8327. }\end{array}$ \\
\hline
\end{tabular}

\section{PENDAHULUAN}

Membaca merupakan kegiatan yang sangat efektif membantu siswa dalam menguasai suatu bahasa (Harmer, 2007). Semakin giat membaca, siswa akan semakin baik dalam memahami sebuah teks, hal ini dikarenakan dengan membaca, siswa mempelajari kosakata baru dan menambah pengetahuan yang bermanfaat bagi mereka dalam menjalani kehidupan yang semakin berkembang seiring kemajuan teknologi. Sehingga, ilmu yang 
diperoleh siswa nantinya membuat mereka mampu menangani suatu masalah mendatang dengan ide kritis dan kreatif yang dimilikinya.

William dan Stoller (2002, sebagaimana dikutip pada Khairunnisa, 2018) menyatakan bahwa membaca merupakan proses kognitif yang berarti menangkap pesan pengarang dari teks tertulis yang dimaksudkan untuk dipahami oleh pembaca dibantu dengan kerja keras dari otak.

Menurut Jismulatif (2019), setiap siswa memiliki kemampuan dan pengalaman yang berbeda dalam belajar membaca, sehingga proses pembelajaran membaca akan efektif menghasilkan pemahaman yang berarti jika dilakukan secara menyeluruh. Lebih lanjut, Jarrell et al., (1983) menyatakan bahwa membaca merupakan pengalaman yang tercermin dalam penguasaan bahasa. Singkatnya, membaca merupakan pengalaman siswa dalam mendapatkan kata-kata baru. Semakin banyak pengalaman mereka, semakin banyak kosakata yang mereka dapatkan. Dengan membaca secara tepat, pembaca bisa mendapatkan lebih banyak ide dan pengetahuan, bahkan banyak hal baru yang belum mereka ketahui sebelumnya.

Kurikulum 2013 menyatakan ada beberapa jenis teks yang harus dipelajari oleh siswa kelas dua di Sekolah Menengah Kejuruan, salah satunya adalah teks naratif. Teks naratif adalah teks yang terdiri dari berbagai peristiwa yang problematis, saling berkaitan secara logis dan kronologis, dan terjadi karena beberapa faktor yang relevan, namun memiliki solusinya sendiri untuk menyelesaikan masalah tersebut (Lukens, 2007). Pada kompetensi dasar kurikulum 2013, siswa diharapkan mampu memahami tujuan dan interpretasi teks tertulis, dan menafsirkan ide pokok teks.

Namun pada hakikatnya, berdasarkan pengalaman penulis selama praktik mengajar di SMK Dar El Hikmah Pekanbaru, masih banyak ditemukan siswa yang mengalami kesulitan ketika harus memahami sebuah teks dengan vocabulary yang terbatas, siswa kurang mengerti cara menentukan dan mengidentifikasi komponen-komponen teks naratif, sehingga menciptakan persepsi siswa yang mengatakan bahasa Inggris itu sulit dan menyebabkan siswa mendapatkan nilai rendah pada saat ujian.

Dalam hal ini, guru diharapkan mampu menerapkan penggunaan strategi pembelajaran yang efektif dalam meningkatkan pemahaman membaca siswa, sehingga siswa merasa mampu memahami teks naratif beserta komponenkomponen dan tujuan teks tersebut. Salah satu metode pembelajaran yang berkaitan dengan peningkatan pemahaman membaca siswa adalah Listen-Read-Discuss (LRD). Manzo \& Casale (2002, pada Sudibyo et al., 2020) menyatakan bahwa Listen-Read-Discuss (LRD) merupakan strategi yang membuat siswa mampu membangun pengetahuan awal sebelum membaca materi pembelajaran selama tahap mendengarkan dan membuat mereka memahami teks dengan mudah selama tahap membaca, dan aktif dalam diskusi kelas.

Melalui strategi ini, guru dapat membangun pengetahuan dasar siswa dengan menuangkan konsep sederhana mengenai materi pembelajaran dalam bentuk graphic organizer yang berisi penjelasan teks naratif secara ringkas. Alasan menetapkan LRD sebagai strategi pembelajaran sebagaimana dinyatakan Manzo dan Casale (1985 dalam Terasne dkk., 2018) bahwa LRD: membantu siswa memahami materi melalui graphic organizer yang disampaikan secara lisan, membangun pengetahuan dasar siswa sebelum membaca teks, dan membantu siswa mencapai pemahaman mereka melalui diskusi kelompok.

Dari uraian di atas, tujuan penelitian dirumuskan untuk menemukan apakah ada pengaruh yang signifikan penggunaan strategi Listen-Read-Discuss (LRD) terhadap peningkatan pemahaman membaca siswa kelas II SMK Dar El Hikmah Pekanbaru.

\section{KAJIAN TEORETIS}

Strategi Listen-Read-Discuss (LRD)

Manzo \& Casale (2002, dalam Sudibyo dkk., 2020) menyatakan bahwa Listen-ReadDiscuss (LRD) merupakan strategi pembelajaran yang membangun pengetahuan siswa sejak tahap mendengar (Listen) dengan menggunakan graphic organizer, membantu siswa memahami teks 
melalui tahap membaca (Read), dan menuntun siswa mencapai pemahaman yang berarti melalui tahap diskusi (Discuss). Lebih lanjut, Manzo mengatakan bahwa strategi Listen-Read-Discuss (LRD) ditujukan kepada guru dan siswa, dimana guru adalah orang yang berperan dalam menerapkan strategi tersebut, sedangkan pemahaman siswa dimaksudkan sebagai tujuan utama dari proses pembelajaran menggunakan strategi yang diterapkan.

Mengacu pada penjelasan yang diutarakan di atas, dapat disimpulkan bahwa strategi Listen-Read-Discuss (LRD) merupakan salah satu strategi pembelajaran yang dilaksanakan oleh guru kepada siswa dengan melibatkan penggunaan graphic organizer sebagai media pembelajaran, yang bertujuan dapat membangun pengetahuan dasar siswa dan membantu mereka dalam mencapai pemahaman berkaitan dengan materi yang diajarkan pada proses belajar dan mengajar.

Strategi Listen-Read-Discuss (LRD) memiliki tiga tahap yang merepresentasikan bentuk pelajaran membaca yakni: 1) guru menyampaikan penjelasan mengenai materi terkait sementara siswa mendengarkan dengan cermat; 2) guru memberikan instruksi kepada siswa untuk membaca teks pilihan sesuai dengan teks yang dijelaskan pada tahap pertama, dilakukan secara individu; 3) guru memberi pengarahan kepada siswa untuk mendiskusikan materi yang relevan dalam sebuah kelompok kecil (McKenna (2002 dalam Ibrahim, 2017)). Hal ini dapat diartikan bahwa guru sebagai motivator pendorong agar siswa mampu melaksanakan proses pembelajaran di dalam kelas dengan baik, sehingga pemahaman siswa yang dirumuskan sebagai tujuan utama dalam penerapan strategi LRD dapat diwujudkan.

Menurut Chamberlain (dalam Daud, 2020), pendidikan telah berkembang seiring dengan perubahan keadaan (pandemi) yang menyebabkan guru harus mengimbanginya dengan melakukan perubahan strategis, namun tetap mengutamakan kualitas ilmu yang akan diperoleh siswa. Dalam menghadapi pandemi yang mengubah sistem pendidikan di Indonesia, guru harus berupaya untuk tetap mengedepankan pendidikan dengan cara yang berbeda. Daud (2020) mengatakan bahwa ranah pendidikan mengalami banyak perubahan yang berarti, yakni penggunaan/pemanfaatan media digital dalam skala besar. Sehingga, penerapan strategi LRD dalam proses pembelajaran dilakukan secara virtual, yakni dengan menggunakan media WhatsApp (WA).

Penerapan strategi Listen-Read-Discuss (LRD) dilaksanakan melalui 3 prosedur pembelajaran, yakni: 1) guru mengirimkan video mengajar berisi penjelasan mengenai materi teks naratif dengan menggunakan media graphic organizer kedalam grup WA, sehingga siswa dapat mendownload, kemudian menonton dan mendengarkan video penjelasan tersebut; 2) guru mengirimkan teks naratif yang relevan terhadap teks yang dijelaskan pada video mengajar sebelumnya ke grup WA, sehingga siswa dapat membaca teks secara individu; 3) guru memberikan instruksi kepada siswa untuk membuat diskusi kelompok kecil dalam grup WA dan mengumpulkan hasil serta dokumentasi diskusi kelompok kepada guru.

\section{METODE PENELITIAN}

Penelitian ini merupakan praeksperimental dengan menggunakan desain one group pre-test-post-test yang berarti satu kelas atau satu kelompok dipilih sebagai sampel, dimana kelas terpilih akan diamati pada dua titik waktu, yaitu sebelum dan setelah treatment. Lebih lanjut, nilai siswa pada pre-test dan post-test akan dibandingkan, sehingga dapat diketahui apakah treatment tersebut berpengaruh terhadap peningkatan belajar siswa atau tidak (Sugiyono, 2013).

Penelitian ini dilakukan di SMK Dar-El Hikmah Pekanbaru, periode semester ganjil tahun ajaran 2020/2021. Sampel dalam penelitian ini adalah siswa kelas dua yang terdiri dari 34 siswa, dipilih menggunakan teknik total sampling. Total sampling merupakan teknik pengambilan sampel dimana jumlah sampelnya sama dengan jumlah populasi (Sugiyono, 2007).

Instrumen penelitian yang digunakan dalam penelitian ini merupakan reading test mengenai teks naratif yang terdiri dari 40 soal 
dalam bentuk multiple-choice test. Menurut King dan Stanley (1989, dalam Pebriana et al., 2019), terdapat lima komponen yang harus difokuskan dalam memahami teks bacaan, diantaranya ialah: finding main idea, finding factual information, guessing vocabulary in context, and identifying reference and inference. Lebih lanjut, Anderson, M \& Anderson, (2003) membagi komponen teks naratif menjadi 3 bagian, yaitu: generic structure, language feature, dan social function. Sehingga, the blueprint of the test dapat diklasifikasikan menjadi 8

komponen, yaitu: finding main idea, finding factual information, guessing vocabulary in context, identifying reference, identifying inference, generic structure, language feature, dan social function.

Siklus pembelajaran yang dilaksanakan pada penelitian pre-eksperimental mencakup pre- test $\left(\mathrm{O}_{1}\right)$, treatment $(\mathrm{X})$, dan post-test $\left(\mathrm{O}_{2}\right)$ sebagaimana di rumuskan dalam skema berikut; $\left(\mathrm{O}_{1} \rightarrow \mathrm{X} \rightarrow \mathrm{O}_{2}\right)$ (Gay et al., 2009).

Penelitian ini menggunakan Statistical Product and Servis Solution (SPSS) 23.0 dan Microsoft Excel 2010 untuk menganalisis data. Lebih lanjut, t-test digunakan untuk membandingkan hasil pre-test dan post-test, sehingga dapat diketahui apakah hipotesis penelitian dapat diterima, dan untuk mengukur apakah treatment dengan penerapan strategi LRD dapat mempengaruhi pemahaman membaca siswa.

Untuk mengklasifikasikan nilai pemahaman membaca siswa, penelitian ini menggunakan "classification of students' scores" yang dikemukakan oleh (Suharsimi, 2013).

Tabel 1. The Classification of Students' Ability Level

\begin{tabular}{cc}
\hline Test Score & Level of Ability \\
\hline $81-100$ & Very Good \\
$66-80$ & Good \\
$56-65$ & Mediocre \\
$40-55$ & Poor \\
$0-39$ & Very Poor \\
\hline
\end{tabular}

(Adopted from Suharsimi, 2013)

\section{HASIL DAN PEMBAHASAN}

Sebelum menerapkan strategi ListenRead-Discuss (LRD) dalam proses pembelajaran, penelitian diawali dengan melakukan try-out test pada siswa kelas dua di Sekolah Menengah Kejuruan yang berbeda, dengan tujuan untuk mengetahui validitas soal. Mengacu pada standard difficulty level yang dikemukakan oleh
(Heaton, 1998), hasil try-out menunjukkan bahwa keseluruhan soal dalam tes diterima dan valid dikarenakan tidak ditemukan soal dengan nilai dibawah 0.30 dan diatas 0.70 , dan diketahui bahwa nilai the reliability of the instrument sebesar 0.86, yang berarti bahwa reliabilitas instrumen sangat tinggi.

Tabel 2. The Reliability of Try-out Test

\begin{tabular}{cc}
\hline Cronbach's Alpha & Nof Items \\
\hline 0.86 & 25 \\
\hline
\end{tabular}




\section{Hasil Pre-test}

Tabel 3. The Students' Pre-test Mean Score

\begin{tabular}{cccccc}
\hline No & Score Range & Frequency & Percentage & Category & Mean Score \\
\hline 1 & $81-100$ & 0 & 0 & Very Good & 60.15 \\
2 & $66-80$ & 6 & 18 & Good & \\
3 & $56-65$ & 15 & 44 & Mediocre & \\
4 & $40-55$ & 13 & 38 & Poor & \\
5 & $0-39$ & 0 & 0 & Very Poor \\
& & & & \multicolumn{2}{c}{ Mediocre }
\end{tabular}

Pertemuan pertama dilaksanakan dengan memberikan pre-test kepada siswa, dengan tujuan untuk mengetahui kemampuan pemahaman membaca siswa pada teks naratif.

Tabel 3 menunjukkan bahwa nilai ratarata siswa pada pre-test adalah 60.15. Diketahui terdapat 6 siswa memperoleh nilai Good, 15 siswa memperoleh nilai Mediocre, dan 13 siswa memperoleh nilai Poor. Berdasarkan data yang di deskripsikan dalam tabel, dapat ditarik kesimpulan bahwa nilai rata-rata siswa pada pretest berada di level Mediocre.

\section{Hasil Post-test}

Tabel 4. The Students' Post-test Mean Score

\begin{tabular}{cccccc}
\hline No & Score Range & Frequency & Percentage & Category & Mean Score \\
\hline 1 & $81-100$ & 7 & 20 & Very Good & 74.97 \\
2 & $66-80$ & 23 & 68 & Good & \\
3 & $56-65$ & 4 & 12 & Mediocre & \\
4 & $40-55$ & 0 & 0 & Poor & \\
5 & $0-39$ & 0 & 0 & Very Poor & \\
\multicolumn{2}{r}{} & Total & 34 & 100 & \multicolumn{2}{c}{ Good } \\
\hline
\end{tabular}

Post-test diberikan kepada siswa di akhir pertemuan, yang dimaksudkan untuk mengetahui kemampuan pemahaman membaca siswa pada teks naratif setelah menerapkan strategi ListenRead-Discuss (LRD) pada proses pembelajaran. Tabel 4 menunjukkan bahwa nilai rata-rata siswa pada

Post-test adalah 74.97. Diketahui terdapat 7 siswa memperoleh nilai Very Good, 23 siswa memperoleh nilai Good, dan 4 siswa memperoleh nilai Mediocre. Melihat data yang di sajikan pada tabel diatas, dapat di simpulkan bahwa nilai ratarata siswa pada post-test berada di level Good.

\section{Paired Sample Statistics}


Tabel 5. Paired Samples Statistics

\begin{tabular}{|c|c|c|c|c|c|}
\hline & & Mean & $N$ & $\begin{array}{c}\text { Std. } \\
\text { Deviation }\end{array}$ & $\begin{array}{c}\text { Std. Error } \\
\text { Mean }\end{array}$ \\
\hline \multirow[t]{2}{*}{$\begin{array}{l}\text { Pair } \\
1\end{array}$} & $\begin{array}{l}\text { Pre- } \\
\text { test }\end{array}$ & 60.15 & 34 & 7.536 & 1.292 \\
\hline & $\begin{array}{l}\text { Post- } \\
\text { test }\end{array}$ & 74.97 & 34 & 7.276 & 1.248 \\
\hline
\end{tabular}

Untuk menjawab rumusan masalah dalam penelitian, yakni; "Adakah pengaruh yang signifikan penggunaan strategi Listen-ReadDiscuss (LRD) dalam meningkatkan pemahaman membaca siswa kelas dua SMK Dar El Hikmah Pekanbaru?", penelitian ini menggunakan Paired Sample Statistics untuk mengetahui nilai mean, standard deviation, dan standard error mean.

Dapat dilihat pada tabel 5, bahwa nilai rata-rata yang berhasil diperoleh pada pre-test adalah 60.15 , dan post-test sebesar 74.97. perbedaan nilai rata-rata antara pre-test dan post- test diketahui sebesar 14.8, yang berarti bahwa terdapat pengaruh yang signifikan dari penerapan strategi LRD terhadap pemahaman membaca siswa. Lebih lanjut, diperoleh nilai standard deviation pada pre-test sebesar 7.536, sementara pada post-test diperoleh nilai sebesar 7.276. Nilai standard error mean pada pre-test diketahui 1.292, dan diperoleh 1.248 pada post-test.

\section{Paired Sample Test}

Tabel 6. Paired Sample Test

\begin{tabular}{|c|c|c|c|c|c|c|c|c|}
\hline & \multicolumn{5}{|c|}{ Paired Differences } & \multirow[b]{3}{*}{$T$} & \multirow{3}{*}{\multicolumn{2}{|c|}{$\begin{array}{r}\text { Sig. (2- } \\
\text { Df } \quad \text { tailed) }\end{array}$}} \\
\hline & \multirow[b]{2}{*}{ Mean } & \multirow{2}{*}{$\begin{array}{c}\text { Std. } \\
\text { Deviation }\end{array}$} & \multirow{2}{*}{$\begin{array}{l}\text { Std. } \\
\text { Error } \\
\text { Mean }\end{array}$} & \multicolumn{2}{|c|}{$\begin{array}{c}95 \% \text { Confidence } \\
\text { Interval of the } \\
\text { Difference }\end{array}$} & & & \\
\hline & & & & Lower & Upper & & & \\
\hline $\begin{array}{l}\text { Pre-test- } \\
\text { Post-test }\end{array}$ & -1.482 & 9.843 & 1.688 & -18.258 & -11.389 & 8.782 & 33 & .000 \\
\hline
\end{tabular}

\section{Paired Sample Test}


Tabel 6. Paired Sample Test

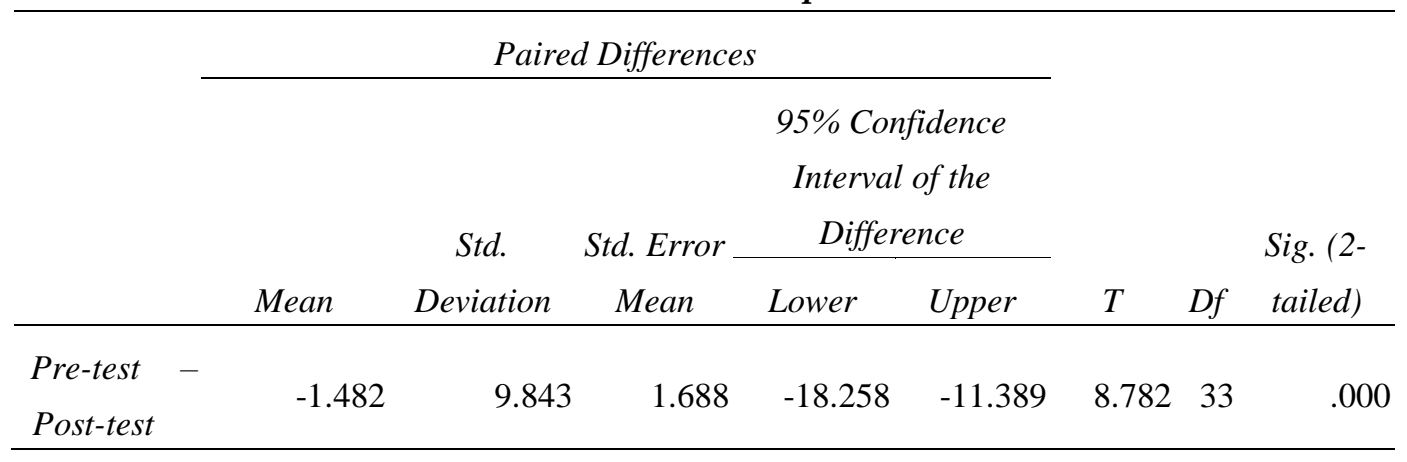

Hasil Paired Samples Test menunjukkan bahwa nilai mean sebesar -1.482 , nilai standard deviation sebanyak 9.843 , nilai standard error mean sebesar 1.688, nilai terendah sebesar 18.258, dan nilai tertinggi diperoleh -11.389. Lebih lanjut, dapat dilihat bahwa nilai t-test sebesar 8.782, yang mana diketahui bahwa nilai $t$ table dari 34 siswa adalah 2.034. hal ini menunjukkan bahwa nilai $t$-test lebih tinggi daripada nilai $t$-table $(8.782>2.034)$. Melihat dari data yang dideskripsikan melalui tabel diatas, dapat dinyatakan bahwa terdapat pengaruh yang signifikan antara pre-test dan post-test. Hal ini membuktikan bahwa strategi LRD ternyata dapat memberikan pengaruh yang signifikan antara pencapaian nilai siswa pada pre-test dan post-test. Sehingga dapat dikatakan bahwa hipotesis alternatif (Ha) pada penelitian ini diterima.

Hasil penelitian menunjukkan bahwa siswa lebih mudah memahami teks yang diberikan oleh peneliti dengan baik dan mereka dapat mengidentifikasi serta memahami komponen teks naratif dengan tepat. Selain itu, siswa juga antusias dalam proses pembelajaran dengan menggunakan strategi Listen-Read-Discuss (LRD) dan berpartisipasi aktif dalam setiap kegiatan pembelajaran. Dari data tersebut, dapat disimpulkan bahwa strategi Listen-Read-Discuss (LRD) efektif untuk siswa kelas dua SMK Dar El Hikmah Pekanbaru.

\section{SIMPULAN DAN REKOMENDASI}

Berdasarkan hasil penelitian yang diperoleh, dapat ditarik kesimpulan bahwa pemahaman membaca siswa pada teks naratif mengalami peningkatan. Peneliti membandingkan hasil pre-test dan post-test dengan menggunakan rumus t-test. Hasil penelitian menunjukkan bahwa nilai rata-rata post-test lebih tinggi dari pada pre-test (74.97 > 60.15). Kemudian, hasil analisis data menunjukkan bahwa $t$-test lebih tinggi dari $t$ table (8.782>2.034). Berdasarkan hasil tersebut, dapat ditarik kesimpulan bahwa Hipotesis Alternatif (Ha) diterima. Data yang diperoleh menunjukkan bahwa terdapat pengaruh yang signifikan penggunaan strategi Listen-ReadDiscuss (LRD) dalam meningkatkan pemahaman membaca siswa kelas dua SMK Dar El Hikmah Pekanbaru.

Rekomendasi berkenaan dengan hasil penelitian ialah agar guru dapat menerapkan strategi pembelajaran dengan penggunaan media yang mudah dipahami oleh siswa, yakni berupa peta konsep sederhana, berkaitan dengan pemanfaatan digital media yang mudah digunakan oleh siswa, sehingga siswa mampu menafsirkan makna tersirat dalam teks, dapat meningkatkan pemahaman membaca terutama pada teks naratif.

\section{DAFTAR PUSTAKA}

Daud, A. (2020). Webinar: Teaching English during Pandemic (New Normal); some Practical https://youtube.be/Qpuf02verFg. 
Anderson, M \& Anderson, K. (2003). Text types in english 3. Journal of Controlled Release, 156(2003).

Gay, L. R., Mills, G., \& Airasian, P. (2009). Ch. 7: Survey Research. New Scientist, 204(2734).

Harmer, J. (2007). How to Teach English (Second Edition). ELT Journal, 62(3). https://doi.org/10.1093/elt/ccn029

Heaton, J. B. (1998). A Practical Guide to the Teaching of English as a Second or Foreign Language. Longman Group UK Limited: England.

Ibrahim, R. (2017). The Use of Listen Read Discuss Strategy and Reading Motivation toward the Students' Reading Comprehension. ELT-Lectura, 4(2). https://doi.org/10.31849/elt-lectura.v4i2.491

Jarrell, C. A., Duffy, G. G., \& Roehler, L. R. (1983). Vocabulary Development. The English Journal, 72(3). https://doi.org/10.2307/816140

Jismulatif, Syofia, F. (2019). An Analysis of Learners' Reading Experience Developing Reading Interest. Proceeding of the URL International Conference on Educational Sciences.

Khairunnisa, P. (2018). The Implementation of LRD (Listen Read Discuss) Strategy on the Students' Ability in Mastering Reading Comprehension at MAS YP Raudhatul Akmal Batang Kuis. Journal of Materials Processing Technology, 1(1).

Lukens, R. J. (2007). A Critical Handbook of Children's Literature. In From Rhyme to Poetry. Addison-wesley educational.

Pebriana, E., Saputri, S. W., \& Qonaatun, A. (2019). The Effectiveness of Listen-Discuss Strategy (LRD) toward Reading Students' Comprehension. Journal of English Language Teaching and Literature (JELTL), 2(1). https://doi.org/10.47080/jeltl.v2i1.538

Sudibyo, D., Setiawan, A., \& Rahmawati, A. (2020). The Influence of Using Listen-ReadDiscuss (LRD) Strategy towards Students' Reading Comprehension on Narrative Text. INTERACTION: Jurnal Pendidikan Bahasa, $7(1)$. https://doi.org/10.36232/jurnalpendidikanbah asa.v7i1.438

Sugiyono. (2013). Metode Penelitian Pendidikan Pendekatan Kuantitaif, Kualitatif, dan R\&D. Bandung CV alfabeta. Metode Penelitian Pendidikan Pendekatan Kuantitaif, Kualitatif, Dan $R \& D$.

Sugiyono, M. P. K. (2007). Kualitataif dan R\&D, Bandung: Alfabeta, 2010. Sugiyono, Metode Penelitian Kuantitatif Kualitatif Dan $R \& D$ Bandung: Alfabeta.

Suharsimi, A. (2013). Dasar-Dasar Evaluasi Pendidikan. In Jakarta: Bumi Aksara.

Terasne, T., Sugianto, N., Wahab, A., \& Ulfa, M. (2018). Improving Students' Reading Comprehension through Listen-ReadDiscuss (LRD) Strategy at MA Nurussabah Praya Tengah. Jo-ELT (Journal of English Language Teaching) Fakultas Pendidikan Bahasa \& Seni Prodi Pendidikan Bahasa Inggris IKIP, 5(2). https://doi.org/10.33394/jo-elt.v5i2.2310 